\title{
Octaarylethynyl and octaarylbutadiynyl phthalocyanines
}

\author{
Clifford C. Leznoff and Bohdan Suchozak
}

\begin{abstract}
Diphenylethynylphthalonitrile, 4,5-di(p-tert-butylphenylethynyl)phthalonitrile, 4,5-di( $p$ neopentoxyphenylethynyl)phthalonitrile, and 4,5-di( $p$-neopentoxyphenyl-1,3-butadiynyl)phthalonitrile were prepared via 4.5-diiodophthalonitrile and the appropriate alkyne in palladium-catalyzed coupling reactions. Condensation of the above alkynylphthalonitriles with lithium 1 -octanolate in 1-octanol afforded the desired polyalkynylphthalocyanines, but only $2,3,9,10,16,17,22,23$-octa ( $p$-neopentoxyphenylethynyl)phthalocyanine and $2,3,9,10,16,17,22,23$-octa $(p$ neopentoxyphenylbutadnyl)phthalocyanine were soluble enough to be suitably characterized.
\end{abstract}

Key words: phthalocyanines, phenylacetylenes, 1-phenyl-1,3-butadiynes.

Résumé : On a préparé le 4,5-diphényléthynylphtalonitrile, le 4,5-di(p-tert-butylphényléthynyl)phtalonitrile, le 4,5-di-( $p$ néopentoxyphényléthynyl)phtalonitrile, le 4,5-di-( $p$-néopentoxyphénylbuta-1,3-diynyl)phtalonitrile en procédant au couplage catalysé par le palladium du 4,5-diiodophtalonitrile avec l'alcyne approprié. La condensation des alcynylphtalonitriles mentionnés plus haut avec de l'octan-1-olate de lithium dans l'octan-1-ol permet d'obtenir les polyalcynylphtalocyanines recherchées; toutefois seules la 2,3,9,10,16,17,22,23-octa( $p$-néopentoxyphényléthynyl)phtalocyanine et la 2,3,9,10,16,17,22,23-octa-( $p$-néopentoxyphénylbutadiynyl)phtalocyanine sont suffisamment solubles pour être caractérisées de façon adéquate.

Mots clés : phtalocyanines, phénylacétylènes, 1-phénylbuta-1,3-diynes.

[Traduit par la Rédaction]

\section{Introduction}

$2,3,9,10,16,17,23,24-$ Octa-substituted phthalocyanines are well-known (1), and have been studied for applications in a wide variety of areas, including dyes (2), chemical sensors (3), nonlinear optics (4), and photodynamic therapy of cancer $(5,6)$. Recently, poly(phenylalkynyl) benzenes $(7)$ and alkynylporphyrins (8) have been described as possible compounds for use in nonlinear optics and arrays $(8,9)$. With this in mind, a series of $2,3,9,10,16,17,23,24$-octaalkynylphthalocyanines were prepared (10) and their ${ }^{1} \mathrm{H}$ NMR spectra studied with respect to their variation in chemical shifts with concentration and temperature. Alkynyl-substituted phthalocyanines (Pcs) have been found to be particularly interesting in that each alkynyl group causes a red shift of 4$6 \mathrm{~nm}$ in the Q-band region of the spectrum, and can hence be applied in "fine-tuning" a Pcs absorption spectrum.

Not investigated in our original series of octaalkynylphthalocyanines were those substituted with phenylethynyl groups, which would be expected to give a greater red shift due to more extensive $\pi$-electron delocalization. Reports of enhanced nonlinear effects in molecules with extreme bond-

Dedicated to Professor Brian James on the occasion of his $65^{\text {th }}$ birthday.

C.C. Leznoff ${ }^{1}$ and B. Suchozak. Department of Chemistry, York University Toronto, ON M3J 1P3, Canada.

${ }^{1}$ Corresponding author (telephone: (416) 736-2100 ext. 33838; fax: (416) 736-5936; e-mail: leznoff@yorku.ca). length alternations (11), including conjugated diynyl systems (12) have also prompted our interest in butadiynyl substituted phthalocyanines. In this paper, the synthesis of some 2,3,9,10,16,17,23,24-octa(phenylethynyl)phthalocyanines will be described. The synthesis of a 4,5-di(butadiynyl)-substituted phthalonitrile is also outlined and its condensation reaction with lithium 1-octanolate will be discussed.

\section{Results and discussion}

Using catalytic quantities of $\mathrm{Pd}\left(\mathrm{PPh}_{3}\right)_{2} \mathrm{Cl}_{2}$ and $\mathrm{CuI}$ in triethylamine (TEA), 4,5-diiodo-phthalonitrile (1) was coupled with 2 molar equiv of phenylacetylene (2), to afford 4,5-di(phenylethynyl)phthalonitrile (3) in $70 \%$ yield (Scheme 1). Subsequent condensation of 3 with lithium 1octanolate in 1-octanol gave, after work-up, a dark green solid which was extremely insoluble in most organic solvents (see Scheme 3 below). Purification of this product, which is believed to be $2,3,9,10,16,17,23,24-$ octa(phenylethynyl)phthalocyanine (4), was made extremely difficult due to its insolubility, and consequently failed to afford satisfactory proton NMR or FAB mass spectra. A recently acquired MALDI-TOF mass spectrometer has allowed us to record the parent ion cluster at (1314) of 4 . However, a UV-vis spectrum of a probe from the reaction mixture at $20 \mathrm{~h}$ seems to suggest the formation of an MPc. This is indicated by a strong absorption maximum at $720 \mathrm{~nm}$, which would correspond to the expected Q-Band absorption of the dilithium Pc.

The high degree of insolubility displayed by the product of this reaction, assuming that it is indeed 4 , was believed to 
Scheme 1.<smiles>N#Cc1cc(I)c(I)cc1C#N</smiles>

Scheme 2.
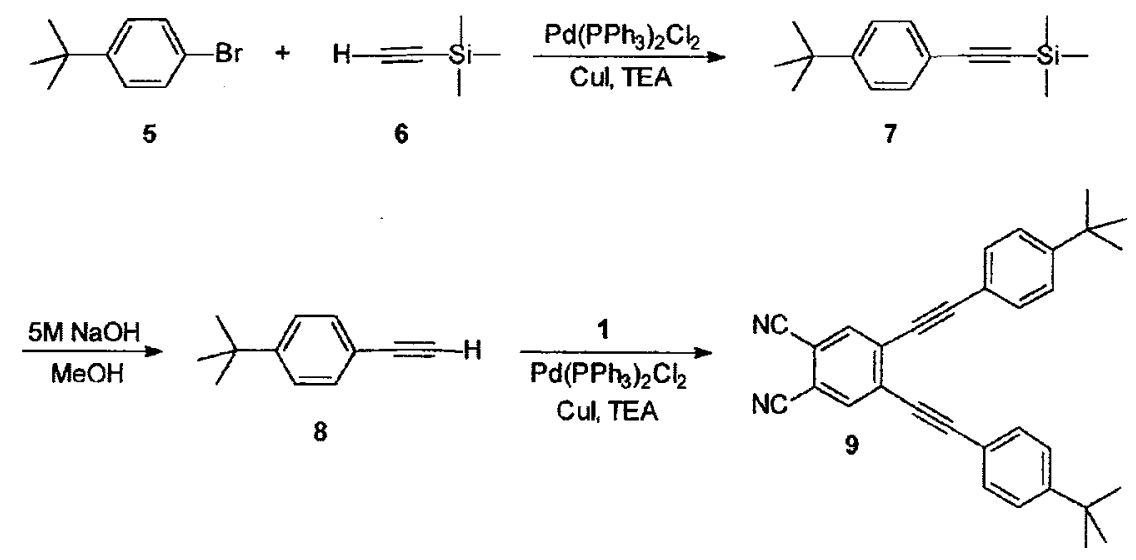

be due to aggregation. In an attempt to minimize these intramolecular aggregative effects, the phenylacetylene moiety was functionalized with the bulky tert-butyl group. Thus, 1-bromo-4-tert-butylbenzene (5) was coupled with trimethylsilylacetylene (6) using $\mathrm{Pd}\left(\mathrm{PPh}_{3}\right)_{2} \mathrm{Cl}_{2}$ and $\mathrm{CuI}$ in TEA in a pressure bottle at $95^{\circ} \mathrm{C}$, to give 1 -trimethylsilyl-2( $p$-tert-butylphenyl)acetylene (7) in $75 \%$ yield. This compound was then deprotected by treatment with aqueous $5 \mathrm{M}$ $\mathrm{NaOH}$ in methanol to give $p$-tert-butylphenylacetylene (8) in $98 \%$ yield. This was subsequently coupled with $4,5-$ diiodophthalonitrile (1), again using $\mathrm{Pd}\left(\mathrm{PPh}_{3}\right)_{2} \mathrm{Cl}_{2}$ and $\mathrm{CuI}$, to afford 4,5-di(p-tert-butylphenylethynyl)phthalonitrile (9) in $88 \%$ yield (Scheme 2 ).

Condensation of 9 to the corresponding Pc (10) was performed using lithium 1-octanolate in 1-octanol at $100^{\circ} \mathrm{C}$ (see Scheme 3 below). A UV-vis probe of this reaction after $22 \mathrm{~h}$ revealed an absorption at $722 \mathrm{~nm}$, believed to be the Q-band absorption of the intermediate dilithium Pc. An acid workup of the reaction was performed to obtain the metal free $\mathrm{Pc}$ 10, but the dark-green product isolated from this reaction was found to be just as insoluble in organic solvents as Pc 4 . Similar difficulties were also encountered in trying to obtain satisfactory NMR and mass spectra, although a MALDITOF mass spectrum of $\mathbf{1 0}$ exhibited a parent ion cluster at $1762 \mathrm{amu}$. If phthalocyanine $\mathbf{1 0} \mathrm{had}$ indeed formed in this reaction, as suggested by the UV-vis spectrum, then it seemed evident that the tert-butyl groups did little to enhance the solubility of these Pcs in their metal-free state.

Previous work in our laboratory has shown that neopentoxy groups are highly effective at increasing the solubility of Pcs (13). It was therefore hoped that by replacing the tert-butyl groups with neopentoxy groups, a more solu- ble octaphenylethynyl Pc could be synthesized and full characterization might be facilitated. The synthesis was initiated with the tosylation of neopentyl alcohol (11) in pyridine to give neopentyl tosylate (12), which was obtained in $85 \%$ yield. Tosylate 12 then reacted with $p$-iodophenol (13) to give $p$-iodoneopentoxybenzene (14) in $82 \%$ yield. This was subsequently coupled with trimethylsilylacetylene (6) using $\mathrm{Pd}\left(\mathrm{PPh}_{3}\right)_{2} \mathrm{Cl}_{2}$ to give 1-trimethylsilyl-2- $(p-$ neopentoxyphenyl)acetylene (15) in $88 \%$ yield. The trimethylsilyl group was then cleaved from 15 using $5 \mathrm{M}$ aq $\mathrm{NaOH}$ in methanol to give, in $97 \%$ yield, $p$ neopentoxyphenylacetylene (16). Terminal alkyne 16 was then coupled with 4,5-diiodophthalonitrile (1), again using $\mathrm{Pd}\left(\mathrm{PPh}_{3}\right)_{2} \mathrm{Cl}_{2}$ as a catalyst, to give $4,5-\mathrm{di}(p-$ neopentoxyphenylethynyl)phthalonitrile (17) in 70\% yield (Scheme 4). Subsequent condensation of 17 in Li-DMAE at $100^{\circ} \mathrm{C}$ (Scheme 3) yielded 2,3,9,10,16,17,23,24-octa $(p$ neopentoxyphenylethynyl)phthalocyanine (18) as a dark green solid, after work-up. Although not exceedingly soluble, Pc 18 was found to dissolve appreciably well in benzene, toluene, $\mathrm{CHCl}_{3}, \mathrm{CH}_{2} \mathrm{Cl}_{2}$, and THF. Purification of this compound was accomplished by column chromatography using flash silica gel and $\mathrm{CH}_{2} \mathrm{Cl}_{2}$ as eluent, followed by gel permeation chromatography using SX-2 Biobeads ${ }^{\mathrm{B}}$ and THF as eluent. This was followed by reprecipitation from benzene-ethanol and then further chromatography, again using flash silica gel and $\mathrm{CH}_{2} \mathrm{Cl}_{2}$. After exhaustive purification, 18 was obtained in an overall yield of $8 \%$.

The UV-vis absorption spectrum of phthalocyanine $\mathbf{1 8}$ in THF is shown in Fig. 1. A broad absorption band was observed in the 600-800 $\mathrm{nm}$ region with an absorption max at $678 \mathrm{~nm}$ and a shoulder at $720 \mathrm{~nm}$. Neither dilution of the so- 
Scheme 3 .

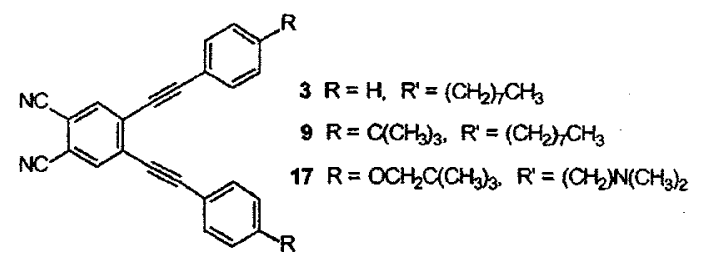

1) $\mathrm{L} / \mathrm{ROH}$

2) $\mathrm{H}^{+}$

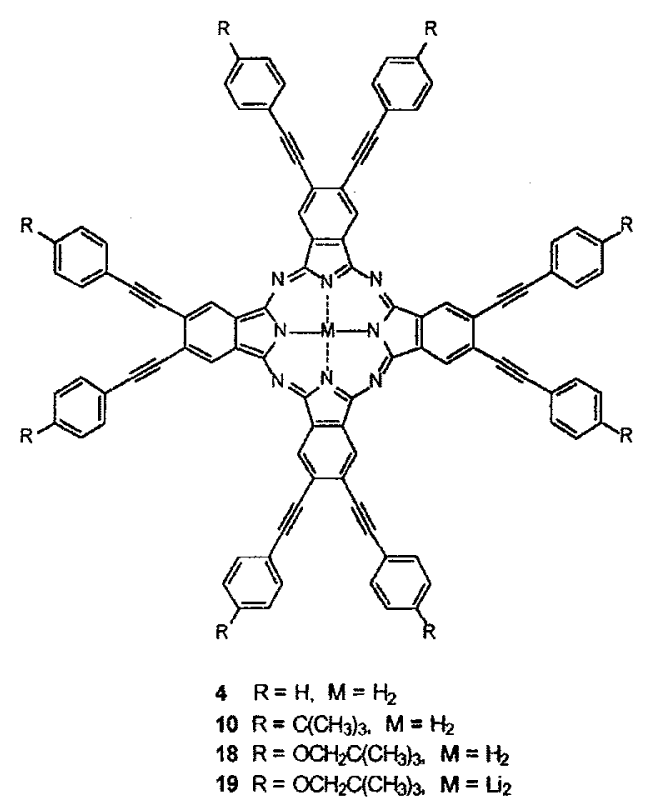

lution, nor heating to $60^{\circ} \mathrm{C}$ caused any observable changes in its spectral patterns. Although the known metal-free octa(alkyl)ethynyl phthalocyanines show a pair of sharp Qband absorptions in the same region (10), this is not the case for 18. The corresponding dilithium $\mathrm{Pc}$ (19) was formed by treating 18 with lithium metal in THF at $50^{\circ} \mathrm{C}$. The UV-vis spectrum of this compound in THF, shown in Fig. 2, displays the same sharp Q-band absorption at $720 \mathrm{~nm}$ as observed in the spectral probes for the condensation reactions of 3 and 9 . This result lends evidence supporting the formation of Pcs 4 and $\mathbf{1 0}$ in the aforementioned reactions.

A comparison of the electronic spectrum of 19 with unsubstituted dilithium phthalocyanine, which displays a $\mathrm{Q}$ band absorption at $688 \mathrm{~nm}$ (14), suggests that the eight peripheral $p$-neopentoxyphenylethynyl groups impart a redshift of approximately $32 \mathrm{~nm}$. Further comparison with the electronic spectrum of a representative octaalkylethynyl Pc, dilithium-2,3,9,10,16,17,23,24-octapentynylphthalocyanine, which displays a Q-band absorption at $700 \mathrm{~nm}$ (15), suggests that the eight peripheral phenyl groups on 19 have the effect of increasing the red-shift in dilithiooctaalkynylphthalocyanines by an additional $20 \mathrm{~nm}$.
Phthalocyanines 18 and 19 were also characterized by ${ }^{1} \mathrm{H}$ NMR spectroscopy in toluene- $d_{8}$ at $300 \mathrm{~K}$, at a concentration of $1.0 \times 10^{-3} \mathrm{M}$. The spectrum of 18 exhibited three broad signals in the aromatic region, one corresponding to the protons on phthalocyanine itself, and the other two corresponding to the protons on the peripheral neopentoxyphenyl rings. The outer neopentoxy groups were observed as a pair of broad singlets, one at $3.48 \mathrm{ppm}$, corresponding to the $\mathrm{OCH}_{2}$ hydrogens and the other at $1.16 \mathrm{ppm}$, corresponding to the hydrogens on the terminal $\mathrm{C}\left(\mathrm{CH}_{3}\right)_{3}$ groups. The two protons on the inner nitrogens however were not observed, and a series of high-temperature ${ }^{1} \mathrm{H}$ NMR experiments were subsequently conducted to determine whether aggregation may have any effect in obscuring this signal. The same sample was rerun at incrementally higher temperatures, ranging from 300 to $363 \mathrm{~K}$, but the signal still remained absent. Only after extreme vertical expansion of the spectra was a very broad singlet detected at $-4.8 \mathrm{ppm}$. Additionally, the previously broad aromatic singlets at $300 \mathrm{~K}$ began to sharpen, and eventually appeared as a pair of doublets (Fig. 3). FAB-MS analysis of 18 exhibited the parent ion (M $+1, m / z=2004$ ), but the elemental analysis exhibited somewhat low carbon values, typical of some Pc compounds. The MALDI-TOF mass spectrum also exhibited a parent ion at 2002 amu. The FAB-MS spectrum for 19 did not show a molecular ion peak, but exhibited rather, two ion clusters that are consistent with the loss of one and two lithium atoms; (M - Li) centred around $m / z=2010$ and $(\mathrm{M}-2 \mathrm{Li})$ centred around $m / z=2004$.

The synthesis of a 4,5-di(butadiynyl)-substituted phthalonitrile was achieved via a palladium-catalyzed crosscoupling between a monosubstituted butadiyne and 4,5diiodophthalonitrile (1). This was accomplished first, by treatment of 16 with an ethyl Grignard and iodine to give 1iodo-2-( $p$-neopentoxyphenyl)acetylene $(\mathbf{2 0})$ in $26 \%$ yield, along with an undesired by-product, 1,4-di( $p$ neopentoxyphenyl)-1,3-butadiyne (21). This was followed by a palladium-catalyzed coupling with trimethylsilylacetylene (6) to give 1-(trimethylsilyl)-4-( $p$ neopentoxyphenyl)-1,3-butadiyne (22) in $29 \%$ yield. Subsequent desilylation using $5 \mathrm{M}$ aq $\mathrm{NaOH}$ in $\mathrm{MeOH}$ at room temperature afforded 1-(p-neopentoxyphenyl)-1,3-butadiyne (23) in $95 \%$ yield. This was followed immediately by a palladium-catalyzed cross-coupling with 1 to give 4,5-di[4-( $p$ neopentoxyphenyl)-1,3-butadiynyl]phthalonitrile (24) in $75 \%$ yield (Scheme 5). Slow heating of this compound on a melting point apparatus showed no melting point below $300^{\circ} \mathrm{C}$, but the addition of a crystal on a hot Kofler block exhibited a sharp decomposition point at $223^{\circ} \mathrm{C}$.

Condensation of $\mathbf{2 4}$ to $2,3,9,10,16,17,23,24$-octa[4-( $p$ neopentoxyphenyl)-1,3-butadiynyl]phthalocyanine (25) was attempted using lithium 1-octanolate in 1 -octanol at $80^{\circ} \mathrm{C}$ (Scheme 6). After $18 \mathrm{~h}$, a UV-vis probe of the dark-green reaction mixture in THF revealed a sharp absorption at $738 \mathrm{~nm}$, which was believed to correspond to the Q-band absorption of the dilithium derivative of 25 . A standard workup procedure was attempted whereby the reaction mixture was treated with dilute aqueous acid, followed by several dissoIution-reprecipitation cycles from EtOH- $\mathrm{H}_{2} \mathrm{O}$. Unexpectedly, upon contact with aqueous acid or water, the previously dark-green reaction mixture turned brown and 
Scheme 4.<smiles>CC(C)(C)CO</smiles>

11

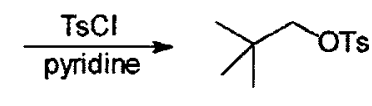

12

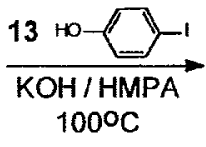

$100^{\circ} \mathrm{C}$

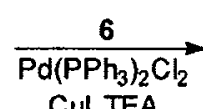

CUI, TEA

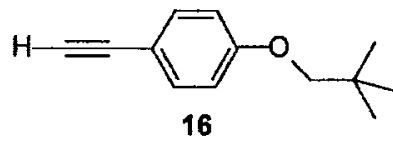

16

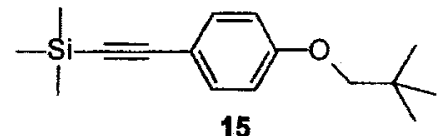

$\underset{\mathrm{MeOH}}{\stackrel{5 \mathrm{NaOH}}{\longrightarrow}}$<smiles>CC(C)(C)COc1ccc(C#Cc2cc(C#N)c(C#N)cc2C#Cc2ccc(OCC(C)(C)C)cc2)cc1</smiles>

Fig. 1. The UV-vis absorption spectrum of Pc 18.

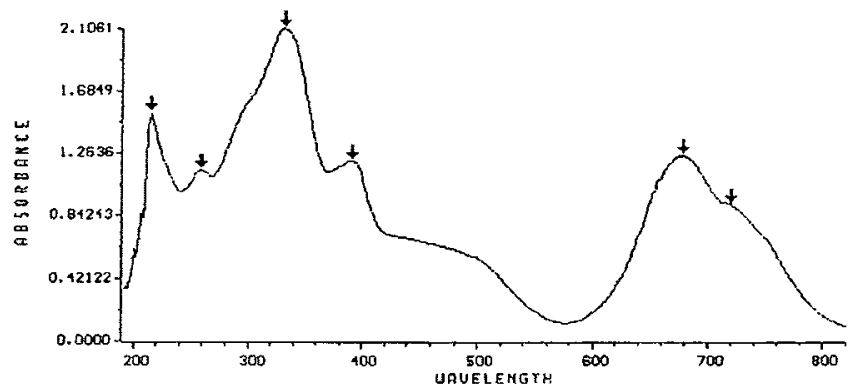

formed a highly insoluble precipitate. A UV-vis spectrum of this material showed almost no absorption in the Q-band region, a result which suggested to us that the $\mathrm{Pc}$ had decomposed or polymerized. Attempts were, therefore, made at isolating the intermediate dilithium Pc (26) under anhydrous conditions by precipitating the reaction mixture into hexane, followed by gel permeation chromatography of the crude product using dry THF and SX-2 Biobeads ${ }^{\mathbb{Q}}$. A dark-green solid was isolated from the column after evaporation of the solvent. An electronic spectrum of this material in THF is shown in Fig. 4. Proton NMR analysis of this material in pyridine- $d_{5}$ at $300 \mathrm{~K}$ showed a spectrum which was consistent with the structure of 26. Two singlets were observed at 1.08 and $3.61 \mathrm{ppm}$, which would correspond to resonances arising from the protons of the eight neopentoxy groups. The aromatic signals arising from the outer neopentoxyphenyl groups corresponded to two doublets centered around 6.92 and $7.67 \mathrm{ppm}$, and the eight benzo protons on the $\mathrm{Pc}$ macrocycle corresponded to a singlet observed at $9.98 \mathrm{ppm}$. Although, this compound proved to be too unstable to give either a satisfactory elemental analysis or FAB mass spectrum, MALDI-TOF mass spectrometry of $\mathbf{2 6}$ did provide a parent ion minus one lithium ion at $2200 \mathrm{amu}$.
Fig. 2. The UV-vis absorption spectrum of Pc 19.

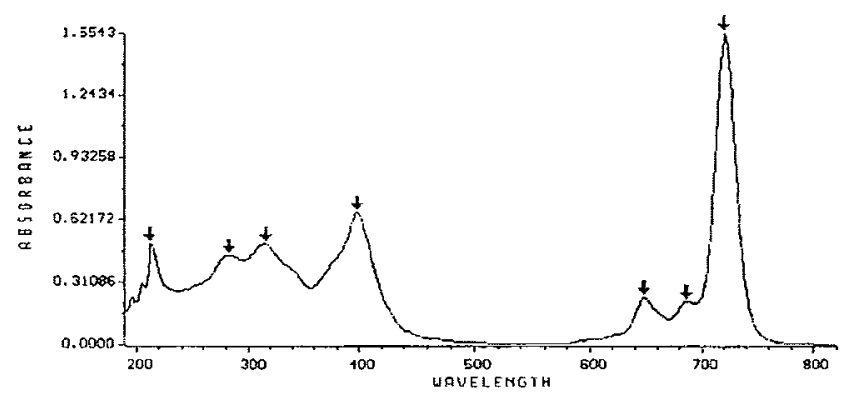

\section{Experimental}

Unless otherwise noted, all reaction processes were performed using magnetic stirring methods under an inert atmosphere of Matheson high-purity argon. All organic solvents were dried by appropriate methods and distilled before use. Ultrasound activation was carried out using a Branson 1200 sonicator. Thin layer chromatography (TLC) was performed using Merck silica gel $60 \mathrm{~F}_{254}$ polyester-backed plates and column chromatography was performed using Caledon flash grade silica gel 60 of particle size $40-63 \mu \mathrm{m}$. Gel permeation chromatography was performed with Bio-Rad SX-2 Biobeads $^{(B)}$, using THF as the eluting solvent. Infrared (IR) spectra were recorded on a Unicam Mattson 3000 FT IR spectrometer using samples prepared as $\mathrm{KBr}$ discs, unless otherwise noted. Ultraviolet-visible (UV-vis) spectra were recorded on a Hewlett-Packard HP8451A diode array spectrophotometer using THF as the solvent. Melting points (mp) were determined using a Kofler hot stage melting point apparatus and are reported uncorrected. Nuclear magnetic resonance (NMR) spectra for proton and carbon were recorded on a Bruker ARX 400 high field Fourier transform 
Fig. 3. The temperature dependent ${ }^{1} \mathrm{H}$ NMR spectra of Pc 18.

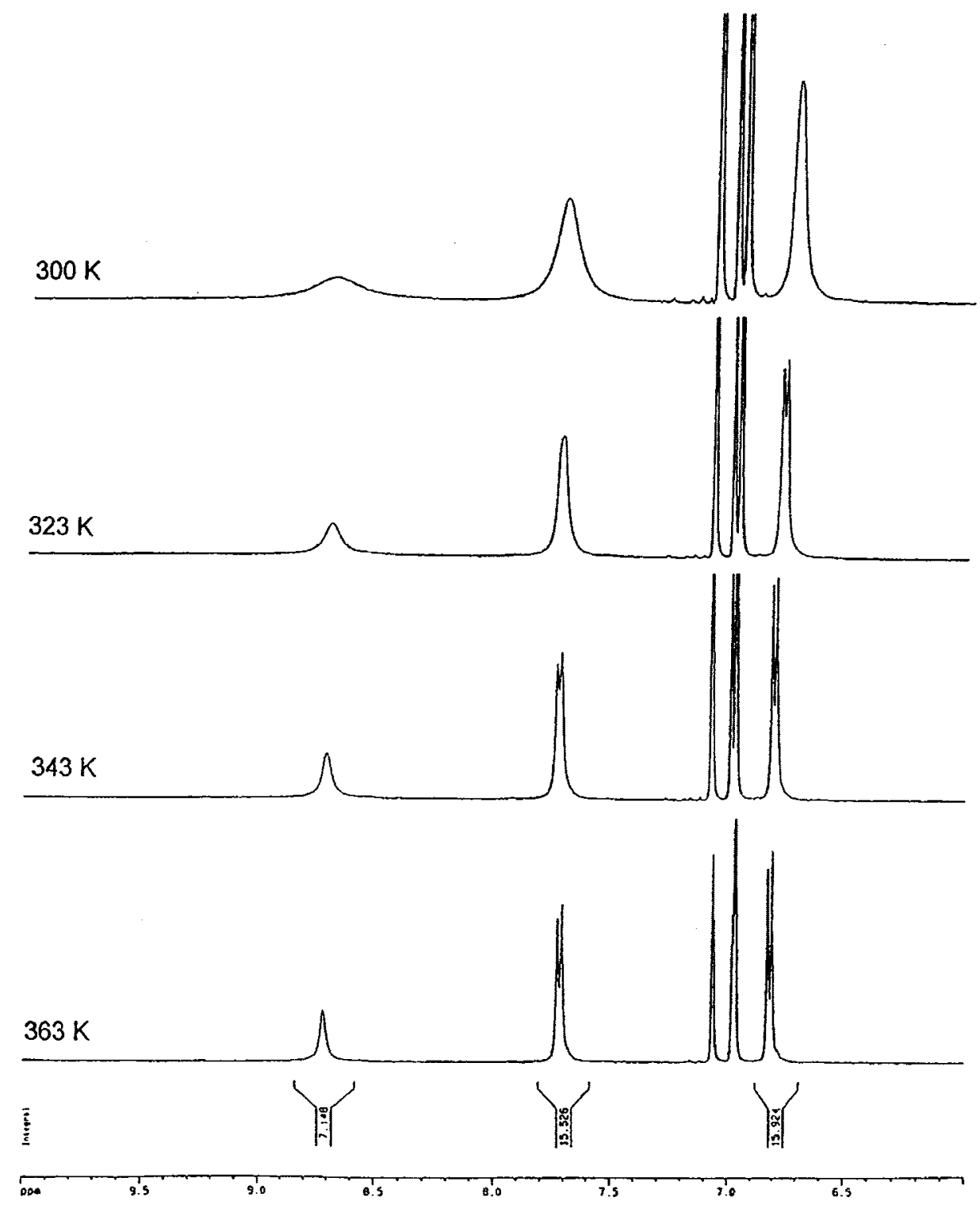

instrument at room temperature unless otherwise stated. Chemical shifts are reported in ppm relative to a tetramethylsilane (TMS) internal standard. Splitting patterns of proton resonances are described as singlets (s), doublets (d), triplets (t), quartets (q), doublet of doublets (dd), multiplets (m), or as broad signals (br). Coupling constants for signals other than singlets and multiplets are reported in $\mathrm{Hz}$. Resonances are reported as the proton decoupled chemical shifts for ${ }^{13} \mathrm{C}$ NMR spectra. Electron-impact mass spectral analyses (EI-MS) were performed by Dr. B. Khouw (York University, Toronto, Ontario, Canada) and Ms. Lisa Nelson (York University, Toronto, Ontario, Canada). MALDI-TOF mass spectra were performed neat using a Voyager Str instrument. Fast atom bombardment (FAB) and high resolution mass spectrometric analyses (HR-MS) were performed by Dr. R. L. Cerny (Nebraska Center for Mass Spectrometry, University of Nebraska-Lincoln, Lincoln, $\mathrm{Ne}$ - braska, U.S.A.). Microanalyses were performed by Guelph Chemical Laboratories Ltd., Guelph, Ontario, Canada.

\section{4,5-Diiodophthalonitrile (1)}

This compound was prepared in three steps according to a published procedure (10) (overall yield 50\% from phthalimide); mp $216-217^{\circ} \mathrm{C}$ (lit. value (10), 216 to $217^{\circ} \mathrm{C}$ ).

\section{4,5-Di(phenylethynyl)phthalonitrile (3) general procedure}

To a solution of $200 \mathrm{mg}(0.53 \mathrm{mmol})$ of $4,5-$ diiodophthalonitrile (1) dissolved in $30 \mathrm{~mL}$ of triethylamine (TEA) was added $36 \mathrm{mg}(0.051 \mathrm{mmol})$ of $\mathrm{Pd}\left(\mathrm{PPh}_{3}\right)_{2} \mathrm{Cl}_{2}$, $10 \mathrm{mg}(0.051 \mathrm{mmol})$ of CuI, and then $0.13 \mathrm{~mL}(0.11 \mathrm{~g}$, $1.2 \mathrm{mmol}$ ) of phenylacetylene (2). The reaction was heated to $60^{\circ} \mathrm{C}$ for $2 \mathrm{~h}$ under argon and then allowed to cool to room temperature overnight. The reaction was analyzed by 
Scheme 5.

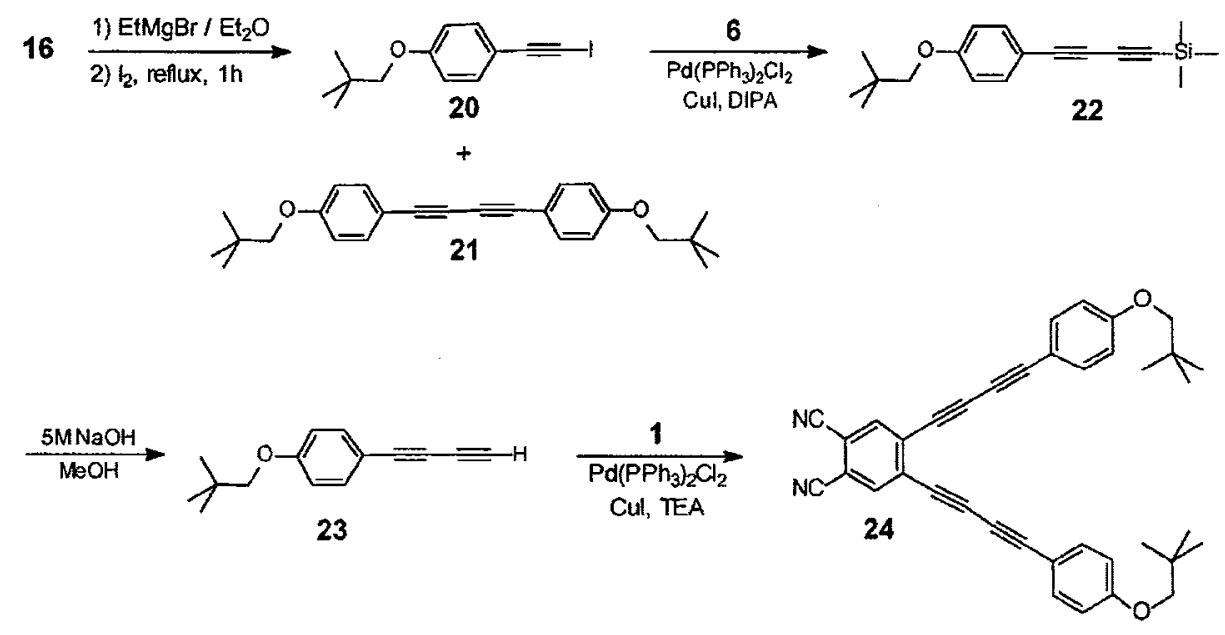

Scheme 6.

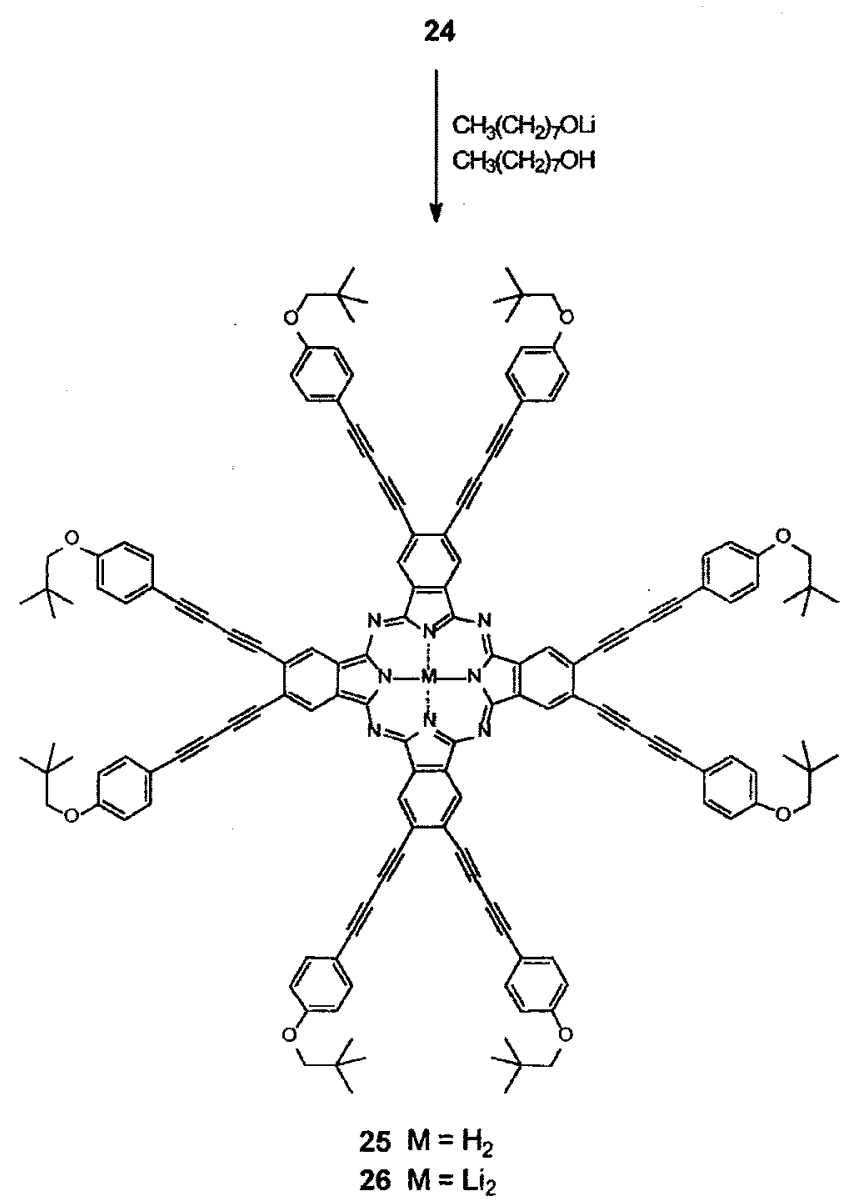

TLC using benzene as eluent, and judged complete by the disappearance of the starting material. The solvent was removed by rotary evaporation at $40^{\circ} \mathrm{C}$, the residue was suspended in ethyl acetate, suction filtered through celite, and then the solvent was removed from the filtrate in vacuo at $40^{\circ} \mathrm{C}$. This brown residue was chromatographed with flash grade silica gel using 98:2 hexane:ethyl acetate to afford 3 as a yellow solid $\left(121 \mathrm{mg}, 70 \%\right.$ yield), mp 190-192 ${ }^{\circ} \mathrm{C}$. EIMS $m / z(\%): 328\left(\mathrm{M}^{+}, 100\right)$. UV-vis (THF) $\lambda_{\max }(\mathrm{nm}): 222$, 276, 301, 345. IR $(\mathrm{KBr})\left(\mathrm{cm}^{-1}\right): 2217(\mathrm{C} \equiv \mathrm{N}) .{ }^{1} \mathrm{H}$ NMR $\left(\mathrm{CDCl}_{3}\right) \delta: 7.93(\mathrm{~s}, 2 \mathrm{H}), 7.59(\mathrm{~d}, J=7.1 \mathrm{~Hz}, 4 \mathrm{H}), 7.43(\mathrm{~m}$, $6 \mathrm{H}) .{ }^{13} \mathrm{C}$ NMR $\left(\mathrm{CDCl}_{3}\right) \delta: 136.34,132.22,131.09,130.21$, $128.92,121.72,114.90,114.27,100.70,85.74$. Anal. calcd. for $\mathrm{C}_{24} \mathrm{H}_{12} \mathrm{~N}_{2}$ : C 87.79, H 3.68, N 8.53; found: C 87.72, H $3.66, \mathrm{~N} 8.42$.

\section{$2,3,9,10,16,17,23,24-$ Octa(phenylethynyl)phthalocyanine (4)}

Lithium metal $(20 \mathrm{mg}, 2.9 \mathrm{mmol}$ ) was added to $2 \mathrm{~mL}$ of 1 -octanol at $60^{\circ} \mathrm{C}$ and allowed to dissolve over $20 \mathrm{~h}$ under argon. After all of the lithium had dissolved, the mixture was cooled to room temperature and then $50 \mathrm{mg}$ $(0.15 \mathrm{mmol})$ of 3 was added. The reaction was heated to $80^{\circ} \mathrm{C}$ and allowed to stir at this temperature for $6 \mathrm{~h}$. The reaction was monitored by TLC using benzene as the eluent. After all of the starting material had disappeared, the reaction was stopped by the addition of $20 \%$ ethanol-water and several drops of $1 \mathrm{M} \mathrm{HCl}$. The reaction mixture was centrifuged, the precipitate was collected, and then washed several times with methanol until the filtrate was colourless. The remaining dark green solid was dried in vacuo to give $10 \mathrm{mg}$ of 4 in a crude yield of $20 \%$. Due to its extreme insolubility in most solvents, this material could not be further purified. MALDI-MS $m / z: 1321.5\left(\mathrm{M}^{+}+\mathrm{Li}\right), 1315.5\left(\mathrm{M}^{+}\right)$. UV-vis (pyridine) $\lambda_{\max }(\mathrm{nm}):$ 726, 650, 396, 306.

\section{1-(p-tert-Butylphenyl)-2-trimethylsilylacetylene (7)}

Into a $100 \mathrm{~mL}$ pressure bottle was placed $0.87 \mathrm{~mL}(1.1 \mathrm{~g}$, $5.0 \mathrm{mmol}$ ) of 1-bromo-4-tert-butylbenzene (5), $0.23 \mathrm{~g}$ $(0.32 \mathrm{mmol})$ of $\mathrm{Pd}\left(\mathrm{PPh}_{3}\right)_{2} \mathrm{Cl}_{2}, 19 \mathrm{mg}(0.10 \mathrm{mmol})$ of $\mathrm{CuI}$, and $50 \mathrm{~mL}$ of TEA. This yellow suspension was degassed with argon for approximately $5 \mathrm{~min}$, and then $1.5 \mathrm{~mL}(1.0 \mathrm{~g}$, $10 \mathrm{mmol}$ ) of (trimethylsilyl)acetylene (6) was added. The bottle was sealed and heated in an oil bath at $95^{\circ} \mathrm{C}$ overnight. The reaction mixture was allowed to cool to room temperature and was then filtered through celite. The solids were washed with ethyl ether until the washings were colourless and the filtrate was evaporated to dryness under reduced pressure. The residue was chromatographed with 
Fig. 4. The UV-vis absorption spectrum of Pc 26.

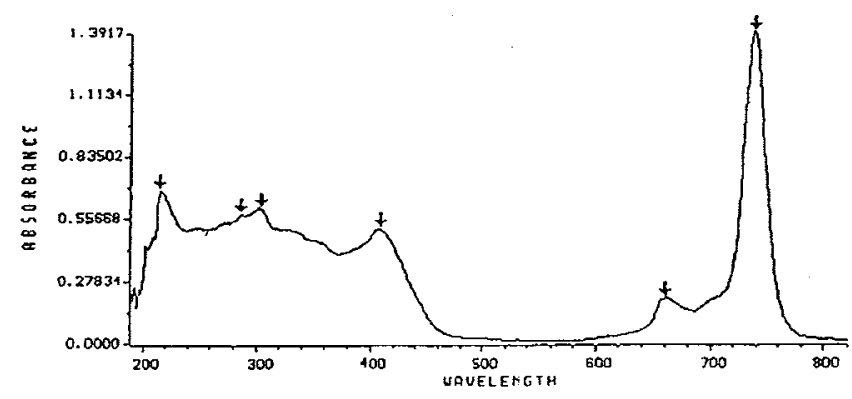

flash grade silica gel using hexane as the eluent to give 7 as a pale yellow oil $(898 \mathrm{mg}, 78 \%$ yield). EI-MS $m / z(\%): 230$ $\left(\mathrm{M}^{+}, 58\right), 215$ (100), ${ }^{1} \mathrm{H}$ NMR $\left(\mathrm{CDCl}_{3}\right) \delta: 7.40(\mathrm{~d}, J=$ $8.6 \mathrm{~Hz}, 2 \mathrm{H}), 7.31(\mathrm{~d}, J=8.5 \mathrm{~Hz}, 2 \mathrm{H}), 1.31(\mathrm{~s}, 9 \mathrm{H}), 0.25(\mathrm{~s}$, $9 \mathrm{H})$. The ${ }^{1} \mathrm{H}$-NMR spectrum matched that of the previously reported compound (16).

\section{p-tert-Butylphenylacetylene (8)}

To a stirred solution of $200 \mathrm{mg}(0.87 \mathrm{mmol})$ of 1 - $(p$-tertbutylphenyl)-2-trimethylsilylacetylene (7) dissolved in $10 \mathrm{~mL}$ of $\mathrm{MeOH}$ was added $0.5 \mathrm{~mL}(2.5 \mathrm{mmol})$ of $5 \mathrm{M}$ $\mathrm{NaOH}$. After $15 \mathrm{~min}$, the reaction mixture was acidified with $1 \mathrm{M} \mathrm{HCl}$, extracted twice with hexane, and the extracts were dried over $\mathrm{MgSO}_{4}$. Filtration, followed by evaporation of the filtrate in vacuo gave 8 as a pale yellow liquid $(134 \mathrm{mg}$, 98\%). IR (neat) $\left(\mathrm{cm}^{-1}\right): 2109(\mathrm{C}=\mathrm{C}) .{ }^{1} \mathrm{HNMR}\left(\mathrm{CDCl}_{3}\right) \delta$ : $7.44(\mathrm{~d}, J=8.6 \mathrm{~Hz}, 2 \mathrm{H}), 7.35(\mathrm{~d}, J=8.1 \mathrm{~Hz}, 2 \mathrm{H}), 3.03(\mathrm{~s}$, 1H), $1.32(\mathrm{~s}, 9 \mathrm{H})$. The ${ }^{1} \mathrm{H}$ NMR spectrum matched that of the previously reported compound (16).

\section{4,5-Di(p-tert-butylphenylethynyl)phthalonitrile (9)}

The same procedure was used as for the synthesis of $\mathbf{3}$, using $1.0 \mathrm{~g}(2.6 \mathrm{mmol})$ of $1,1.0 \mathrm{~g}(6.3 \mathrm{mmol})$ of $8,222 \mathrm{mg}$ $(0.32 \mathrm{mmol})$ of $\mathrm{Pd}\left(\mathrm{PPh}_{3}\right)_{2} \mathrm{Cl}_{2}, 30 \mathrm{mg}(0.16 \mathrm{mmol})$ of $\mathrm{CuI}$, and $30 \mathrm{~mL}$ of TEA to give $1.0 \mathrm{~g}$ of 9 in $88 \%$ yield, $\mathrm{mp} 168$ to $169^{\circ} \mathrm{C}$. EI-MS $m / z(\%): 440\left(\mathrm{M}^{+}, 60\right), 426(100)$. UV-vis (THF) $\lambda_{\max }(\mathrm{nm}): 214,279,309,354$. IR (KBr) $\left(\mathrm{cm}^{-1}\right): 2213$ $(\mathrm{C} \equiv \mathrm{N}) .{ }_{\mathrm{H}}^{\mathrm{N} M R}\left(\mathrm{CDCl}_{3}\right) \delta: 7.91(\mathrm{~s}, 2 \mathrm{H}), 7.53(\mathrm{~d}, J=$ $8.4 \mathrm{~Hz}, 4 \mathrm{H}), 7.43(\mathrm{~d}, J=8.6 \mathrm{~Hz}, 4 \mathrm{H}), 1.36(\mathrm{~s}, 18 \mathrm{H}) .{ }^{13} \mathrm{C}$ NMR $\left(\mathrm{CDCl}_{3}\right) \delta: 153.81,136.36,132.09,131.23,125.96$, $118.79,115.04,113.99,101.09,85.45,35.27,31.34$. Anal. calcd. for $\mathrm{C}_{32} \mathrm{H}_{28} \mathrm{~N}_{2}$ : C 87.24, $\mathrm{H} 6.41, \mathrm{~N} 6.36$; found: $\mathrm{C}$ 87.25, H 6.42, N 6.12 .

\section{$2,3,9,10,16,17,23,24-O c t a(p-$ tert-}

\section{butylphenylethynyl)phthalocyanine (10)}

Lithium metal (16 mg, $2.3 \mathrm{mmol}$ ) was added to $3 \mathrm{~mL}$ of 1-octanol at $80^{\circ} \mathrm{C}$ and allowed to dissolve over $20 \mathrm{~h}$ under argon. After all of the lithium had dissolved, the mixture was cooled to room temperature and then $200 \mathrm{mg}$ $(0.45 \mathrm{mmol})$ of 9 was added. The reaction was heated to $110^{\circ} \mathrm{C}$ and allowed to stir at this temperature for $15 \mathrm{~h}$. The reaction was monitored by TLC using benzene as the eluent. After all of the starting material had disappeared, the reaction was stopped by the addition of $20 \%$ ethanol-water and several drops of $1 \mathrm{M} \mathrm{HCl}$. The reaction mixture was centrifuged, the precipitate was collected, and then washed several times with methanol until the filtrate was colourless. The re- maining dark-green solid was dried in vacuo to give $30 \mathrm{mg}$ of 10 in a crude yield of $15 \%$. Due to its extreme insolubility in most solvents, this material could not be further purified. MALDI-MS $m / z$ : $1770.8\left(\mathrm{M}^{+}+\mathrm{Li}\right), 1764.8\left(\mathrm{M}^{+}\right)$. UVvis (pyridine) $\lambda_{\max }(\mathrm{nm}): 726,656,398,316$.

\section{Neopentyl tosylate (12)}

To a stirred, ice water cooled solution of $50 \mathrm{~g}(0.57 \mathrm{~mol})$ of neopentyl alcohol (11) in $350 \mathrm{~mL}$ of pyridine was slowly added a solution of $162 \mathrm{~g}(0.85 \mathrm{~mol})$ of $p$-toluenesulfonyl chloride in $200 \mathrm{~mL}$ pyridine. The resulting cloudy brown mixture was allowed to stir overnight at room temperature, after which time the pyridine was removed by rotary evaporation at $45^{\circ} \mathrm{C}$. To the remaining residue was added $300 \mathrm{~mL}$ of ice-cold water, and the mixture was stirred for $1 \mathrm{~h}$. The mixture was extracted three times with $200 \mathrm{~mL}$ portions of ethyl ether, and the combined organic layers were washed with successive $200 \mathrm{~mL}$ portions of $1 \mathrm{M} \mathrm{HCl}$, sat. $\mathrm{NaHCO}_{3}$, $\mathrm{H}_{2} \mathrm{O}$, and then brine. The extract was dried over $\mathrm{MgSO}_{4}$, filtered, and the solvent was removed in vacuo to leave 12 as an amber oil. This crude product was crystallized from $\mathrm{MeOH}-\mathrm{H}_{2} \mathrm{O}$ to afford a white crystalline solid $(116 \mathrm{~g}, 85 \%$ yield), $\mathrm{mp} 48$ to $49^{\circ} \mathrm{C}$ (lit. value (17), 47 to $48^{\circ} \mathrm{C}$ ). ${ }^{1} \mathrm{H}$ NMR $\left(\mathrm{CDCl}_{3}\right) \delta: 7.76(\mathrm{~d}, J=8.4 \mathrm{~Hz}, 2 \mathrm{H}), 7.32(\mathrm{~d}, J=8.1 \mathrm{~Hz}$, $2 \mathrm{H}), 3.63(\mathrm{~s}, 2 \mathrm{H}), 2.42(\mathrm{~s}, 3 \mathrm{H}), 0.87(\mathrm{~s}, 9 \mathrm{H}) .{ }^{13} \mathrm{C}$ NMR $\left(\mathrm{CDCl}_{3}\right) \delta: 144.75,133.20,129.91,127.97,79.59,31.71$, $26.10,21.69$.

\section{p-Iodoneopentoxybenzene (14)}

A mixture of $10 \mathrm{~g}$ (45 mmol) of 4-iodophenol (13), $12.1 \mathrm{~g}$ $(50 \mathrm{mmol})$ of neopentyl tosylate $(12)$, and $2.8 \mathrm{~g}(50 \mathrm{mmol})$ of potassium hydroxide in $30 \mathrm{~mL}$ of hexamethylphosphoramide (HMPA) (Caution: Carcinogen) was vigorously stirred at $100^{\circ} \mathrm{C}$ for 3 days. This mixture was then poured into $300 \mathrm{~mL}$ of $\mathrm{H}_{2} \mathrm{O}$ and extracted three times with $100 \mathrm{~mL}$ portions of ethyl ether. The combined ether extracts were successively washed with $100 \mathrm{~mL}$ portions of $\mathrm{H}_{2} \mathrm{O}, 1 \mathrm{M} \mathrm{HCl}$, $\mathrm{H}_{2} \mathrm{O}$, and then brine, followed by drying over $\mathrm{MgSO}_{4}$, filtration and removal of the solvent by rotary evaporation. The remaining amber oil was chromatographed using silica gel and hexane as eluent to afford $\mathbf{1 4}$ as a clear, colourless liquid (10.8 g, 82\% yield). EI-MS $m / z(\%): 290\left(\mathrm{M}^{+}, 60\right), 220$ (100). UV-vis (THF) $\lambda_{\max }(\mathrm{nm}): 234,282 .{ }^{1} \mathrm{H} \mathrm{NMR}\left(\mathrm{CDCl}_{3}\right)$ $\delta: 7.54(\mathrm{~d}, J=8.8 \mathrm{~Hz}, 2 \mathrm{H}), 6.68(\mathrm{~d}, J=8.8 \mathrm{~Hz}, 2 \mathrm{H}), 3.55(\mathrm{~s}$, $2 \mathrm{H}), 1.03(\mathrm{~s}, 9 \mathrm{H}) .{ }^{13} \mathrm{C}$ NMR $\left(\mathrm{CDCl}_{3}\right) \delta: 159.65,138.27$, $117.17,82.50,78.16,32.05,26.78$. Anal. calcd. for $\mathrm{C}_{11} \mathrm{H}_{15} \mathrm{IO}$ : C 45.54, H 5.21; found: C 45.47, H 5.36.

\section{1-Trimethylsilyl-2-(p-neopentoxyphenyl)acetylene (15)}

The same procedure was used as for the synthesis of $\mathbf{3}$, using $8.0 \mathrm{~g}(28 \mathrm{mmol})$ of $14,4.7 \mathrm{~mL}(3.3 \mathrm{~g}, 33 \mathrm{mmol})$ of trimethylsilylacetylene (6), $968 \mathrm{mg}(1.4 \mathrm{mmol})$ of $\mathrm{Pd}\left(\mathrm{PPh}_{3}\right)_{2} \mathrm{Cl}_{2}, 263 \mathrm{mg}(1.4 \mathrm{mmol})$ of $\mathrm{CuI}$, and $300 \mathrm{~mL}$ of TEA, except that the entire reaction was carried out at room temperature. The crude product was chromatographed using silica gel and hexane as eluent to afford 15 as a white solid $\left(6.3 \mathrm{~g}, 88 \%\right.$ yield), $\mathrm{mp} 78$ to $79^{\circ} \mathrm{C}$. EI-MS $\mathrm{m} / \mathrm{z}(\%): 260$ $\left(\mathrm{M}^{+}, 40\right), 245(20), 190(50), 175(100) . \mathrm{UV}$-vis (THF) $\lambda_{\max }$ (nm): 214, 261. IR (KBr) $\left(\mathrm{cm}^{-1}\right): 2157(\mathrm{C} \equiv \mathrm{C}) .{ }^{1} \mathrm{H}$ NMR $\left(\mathrm{CDCl}_{3}\right) \delta: 7.39(\mathrm{~d}, J=8.4 \mathrm{~Hz}, 2 \mathrm{H}), 6.81(\mathrm{~d}, J=8.6 \mathrm{~Hz}$, $2 \mathrm{H}), 3.59(\mathrm{~s}, 2 \mathrm{H}), 1.04(\mathrm{~s}, 9 \mathrm{H}), 0.25(\mathrm{~s}, 9 \mathrm{H}) .{ }^{13} \mathrm{C}$ NMR 
$\left(\mathrm{CDCl}_{3}\right) \delta: 160.02,133.62,115.17,114.60,105.63,92.39$, 78.08, 32.08, 26.80, 0.32. Anal. calcd. for $\mathrm{C}_{16} \mathrm{H}_{24} \mathrm{OSi}$ : $\mathrm{C}$ 73.79, H 9.29; found: C 73.40, H 9.23.

\section{$p$-Neopentoxyphenylacetylene (16)}

The same procedure was used as for the synthesis of $\mathbf{8}$, using $10 \mathrm{~g}(38 \mathrm{mmol})$ of $15,23 \mathrm{~mL}(115 \mathrm{mmol})$ of $5 \mathrm{M}$ $\mathrm{NaOH}$, and $600 \mathrm{~mL}$ of $\mathrm{MeOH}$ to afford 16 . The crude product was chromatographed using silica gel and hexane as eluent giving the title compound as a clear, colourless oil $(6.5 \mathrm{~g}, 95 \%$ yield $)$. EI-MS $m / z(\%): 188\left(\mathrm{M}^{+}, 10\right), 118(100)$. UV-Vis (THF) $\lambda_{\max }(\mathrm{nm}): 213,252,293,318,343$. IR (neat) $\left(\mathrm{cm}^{-1}\right): 2107(\mathrm{C}=\mathrm{C}) .{ }^{1} \mathrm{H}$ NMR $\left(\mathrm{CDCl}_{3}\right) \delta: 7.42(\mathrm{~d}, J=$ $8.7 \mathrm{~Hz}, 2 \mathrm{H}), 6.84(\mathrm{~d}, J=8.6 \mathrm{~Hz}, 2 \mathrm{H}), 3.60(\mathrm{~s}, 2 \mathrm{H}), 2.99(\mathrm{~s}$, $1 \mathrm{H}), 1.04(\mathrm{~s}, 9 \mathrm{H}) .{ }^{13} \mathrm{C} \mathrm{NMR}\left(\mathrm{CDCl}_{3}\right) \delta: 160.21,133.73$, $114.71,114.03,84.05,78.11,75.81,32.08,26.78$. Anal. calcd. for $\mathrm{C}_{13} \mathrm{H}_{16} \mathrm{O}$ : C 82.94, H 8.57; found: C $82.20, \mathrm{H}$ 8.39 .

\section{4,5-Di(p-neopentoxyphenylethynyl)phthalonitrile (17)}

The same procedure was used as for the synthesis of $\mathbf{3}$, using $760 \mathrm{mg}(2.0 \mathrm{mmol})$ of $1,791 \mathrm{mg}$ (4.2 mmol) of 16, $147 \mathrm{mg}(0.32 \mathrm{mmol})$ of $\mathrm{Pd}\left(\mathrm{PPh}_{3}\right)_{2} \mathrm{Cl}_{2}, 40 \mathrm{mg}(0.16 \mathrm{mmol})$ of $\mathrm{CuI}$, and $25 \mathrm{~mL}$ of TEA to give $700 \mathrm{mg}$ of 17 in $70 \%$ yield, $\mathrm{mp} 168-170^{\circ} \mathrm{C}$. EI-MS $m / z(\%): 501\left(\mathrm{M}^{\dagger}, 18\right), 500(55), 360$ (100). UV-vis (THF) $\lambda_{\max }$ (nm): $214,252,284,325,366$. IR $(\mathrm{KBr})\left(\mathrm{cm}^{-1}\right): 2209(\mathrm{C} \equiv \mathrm{N}) .{ }^{1} \mathrm{H}$ NMR $\left(\mathrm{CDCl}_{3}\right) \delta: 7.87(\mathrm{~s}$, $2 \mathrm{H}), 7.51(\mathrm{~d}, J=8.6 \mathrm{~Hz}, 4 \mathrm{H}), 6.92(\mathrm{~d}, J=8.7 \mathrm{~Hz}, 4 \mathrm{H}), 3.64$ $(\mathrm{s}, 4 \mathrm{H}), 1.06(\mathrm{~s}, 18 \mathrm{H}),{ }^{13} \mathrm{C}$ NMR (acetone- $\left.d_{6}\right) \delta: 162.37$, $137.24,134.80,131.70,116.33,116.03,114.91,114.66$, $101.51,86.12,79.12,32.69,27.02$. Anal. calcd. for $\mathrm{C}_{34} \mathrm{H}_{32} \mathrm{~N}_{2} \mathrm{O}_{2}$ : C $81.57, \mathrm{H} 6.44, \mathrm{~N} 5.60$; found: $\mathrm{C} 81.00, \mathrm{H}$ $6.45, \mathrm{~N} 5.44$.

\section{$2,3,9,10,16,17,23,24-O c t a(p-$ \\ neopentoxyphenylethynyl)phthalocyanine (18)}

To $2.5 \mathrm{~mL}$ of dimethylaminoethanol (DMAE) was added $30 \mathrm{mg}(4.3 \mathrm{mmol})$ of lithium metal. After the metal had completely dissolved, $200 \mathrm{mg}(0.4 \mathrm{mmol})$ of 17 was added to the well-stirred alkoxide solution, and the reaction mixture was heated to $100^{\circ} \mathrm{C}$ for $15 \mathrm{~h}$. After this time, the reaction mixture was cooled to room temperature and diluted with $10 \mathrm{~mL}$ of $20 \% \mathrm{MeOH}-\mathrm{H}_{2} \mathrm{O}$. After being allowed to stand for $90 \mathrm{~min}$, the reaction mixture was centrifuged and the crude Pc was collected, dissolved in THF and precipitated from hexane. This crude pigment was chromatographed using silica gel and $\mathrm{CH}_{2} \mathrm{Cl}_{2}$ as eluent, followed by gel permeation chromatography using SX-2 Biobeads ${ }^{3}$ and THF as eluent. This material was further purified by reprecipitation from benzene-ethanol and then by chromatography using silica gel and $\mathrm{CH}_{2} \mathrm{Cl}_{2}$ as eluent to give 18 as a dark green solid (64 $\mathrm{mg}, 8 \%$ yield). FAB-MS: 2004. MALDI-MS $m / z: 2003.9\left(\mathrm{M}^{+}\right)$. UV-vis (THF) $\lambda_{\max }$ $(\mathrm{nm})(\log \epsilon): 716(6.08), 678(6.19), 390(6.18), 330(6.41)$, 258 (6.14), 216 (6.23). ${ }^{1} \mathrm{H}$ NMR (toluene- $d_{8}, 1.0 \times 10^{-3} \mathrm{M}$, $363 \mathrm{~K}) \delta: 8.71(\mathrm{br}, 8 \mathrm{H}), 7.71(\mathrm{~d}, J=7.8 \mathrm{~Hz}), 6.81(\mathrm{~d}, J=$ $8.1 \mathrm{~Hz}), 3.58(\mathrm{~s}, 16 \mathrm{H}), 1.14(\mathrm{~s}, 72 \mathrm{H}),-4.81(\mathrm{br}, 2 \mathrm{H})$. Anal. calcd. for $\mathrm{C}_{136} \mathrm{H}_{130} \mathrm{~N}_{8} \mathrm{O}_{8}$ : C 81.49, H 6.54, N 5.59; found: $\mathrm{C}$ 80.06 , H 5.80, N 5.27.

\section{$[2,3,9,10,16,17,23,24-\operatorname{Octa}(p-$}

neopentoxyphenylethynyl)phthalocyaninyl]dilithium (19)

To a suspension of $10 \mathrm{mg}(0.72 \mathrm{mmol})$ of lithium metal in $2 \mathrm{~mL}$ of dry THF was added $2 \mathrm{mg}\left(1.0 \times 10^{-3} \mathrm{mmol}\right)$ of $\mathrm{Pc}$ 18. The mixture was stirred at $50^{\circ} \mathrm{C}$ for 5 days, after which time the excess lithium was removed by filtration and the solvent was removed in vacuo at $40^{\circ} \mathrm{C}$ to give $19(2 \mathrm{mg}$, 100\% yield). FAB-MS: $2010(\mathrm{M}-\mathrm{Li}), 2004(\mathrm{M}-2 \mathrm{Li})$. UV-vis (THF) $\lambda_{\max }(\mathrm{nm})(\log \epsilon): 720(6.89), 686(6.04), 648$ (6.07), 398 (6.52), $316(6.40), 282(6.35), 212(6.40),{ }^{1} \mathrm{H}$ NMR (pyridine- $\left.d_{5}, 4.0 \times 10^{-4} \mathrm{M}, 333 \mathrm{~K}\right) \delta: 8.86(\mathrm{br}, 8 \mathrm{H})$, 7.75 (br, 16H), $6.79(\mathrm{~d}, J=7.4 \mathrm{~Hz}), 3.53(\mathrm{~s}, 16 \mathrm{H}), 1.12(\mathrm{~s}$, $72 \mathrm{H})$.

\section{1-Iodo-2-(p-neopentoxyphenyl)acetylene (20)}

To $11.5 \mathrm{~mL}$ (35 mmol) of ethylmagnesium bromide (3.0 M solution in ether) was slowly added a solution of $5.0 \mathrm{~g}(27 \mathrm{mmol})$ of $p$-neopentoxyphenylacetylene (16) in $15 \mathrm{~mL}$ of anhydrous ether. The reaction mixture was then heated to reflux as $6.7 \mathrm{~g}(23 \mathrm{mmol})$ of powdered iodine was slowly added through the top of the condenser. The solution was refluxed for another hour, allowed to cool to room temperature and then poured into $150 \mathrm{~mL}$ of $\mathrm{H}_{2} \mathrm{O}$. The mixture was acidified with glacial acetic acid, the ether layer was separated, and the aqueous layer was extracted twice with $50 \mathrm{~mL}$ portions of ether. The combined organic extracts were washed with sat. $\mathrm{Na}_{2} \mathrm{~S}_{2} \mathrm{O}_{3}$, sat. $\mathrm{NaHCO}_{3}, \mathrm{H}_{2} \mathrm{O}$, and brine, then dried over $\mathrm{MgSO}_{4}$, filtered and evaporated under reduced pressure. The title compound $(\mathbf{2 0})$ was obtained as a white solid after recrystallization from $\mathrm{MeOH}-\mathrm{H}_{2} \mathrm{O}(2.2 \mathrm{~g}$, $26 \%$ yield), mp 54 to $55^{\circ} \mathrm{C}$. EI-MS $m / z(\%): 314\left(\mathrm{M}^{+}, 35\right)$, 244 (100), 118 (65). UV-vis (THF) $\lambda_{\text {max }}(\mathrm{nm}): 214,262$. IR $(\mathrm{KBr})\left(\mathrm{cm}^{-1}\right): 2166(\mathrm{C} \equiv \mathrm{C}) .{ }^{1} \mathrm{H}$ NMR $\left(\mathrm{CDCl}_{3}\right) \delta: 7.36(\mathrm{~d}, J=$ $8.7 \mathrm{~Hz}, 2 \mathrm{H}), 6.83(\mathrm{~d}, J=8.7 \mathrm{~Hz}, 2 \mathrm{H}), 3.59(\mathrm{~s}, 2 \mathrm{H}), 1.03(\mathrm{~s}$, 9H). ${ }^{13} \mathrm{C} \mathrm{NMR}\left(\mathrm{CDCl}_{3}\right)$ 8: 160.26, 133.94, 115.45, 114.62, 94.38, 78.13, 32.08, 26.79, 3.56. Anal. calcd. for $\mathrm{C}_{13} \mathrm{H}_{15} \mathrm{IO}$ : C 49.70 , H 4.81; found: C 50.06, H 4.78 .

The by-product, 1,4-di-( $p$-neopentoxyphenyl)-1,3butadiyne (21), was obtained in $59 \%$ yield $(2.9 \mathrm{~g})$ as a white solid, mp $189-191^{\circ} \mathrm{C}$. UV-vis (THF) $\lambda_{\max }(\mathrm{nm}): 214,269$, $282,300,320,343$. IR (KBr) $\left(\mathrm{cm}^{-1}\right): 2388,2139,1601$, $1503,1291,1247,1166,1016,831 .{ }^{1} \mathrm{H} \mathrm{NMR}\left(\mathrm{CDCl}_{3}\right) \delta$ : $7.44(\mathrm{~d}, J=8.7 \mathrm{~Hz}, 2 \mathrm{H}), 6.85(\mathrm{~d}, J=8.7 \mathrm{~Hz}, 2 \mathrm{H}), 3.60(\mathrm{~s}$, $2 \mathrm{H}), 1.04(\mathrm{~s}, 9 \mathrm{H}) \cdot{ }^{13} \mathrm{C}$ NMR $\left(\mathrm{CDCl}_{3}\right) \delta: 160.50,134.19$, $114.89,113.85,81.59,78.16,73.10,32.09,26.78$. EI-MS $m / z \quad \%): 374\left(\mathrm{M}^{+}, 50\right), 234$ (100). Anal. calcd. for $\mathrm{C}_{26} \mathrm{H}_{30} \mathrm{O}_{2}$ : C 83.38, H 8.07; found: C 82.90, H 8.40.

\section{1-(Trimethylsilyl)-4-(p-neopentoxyphenyl)-1,3-butadiyne (22)}

To a solution containing $200 \mathrm{mg}(0.64 \mathrm{mmol})$ of $\mathbf{2 0}$ dissolved in $5 \mathrm{~mL}$ of THF were added $22 \mathrm{mg}(0.032 \mathrm{mmol})$ of $\mathrm{Pd}\left(\mathrm{PPh}_{3}\right)_{3} \mathrm{Cl}_{2}, 3.0 \mathrm{mg}(0.016 \mathrm{mmol})$ of $\mathrm{CuI}, 0.16 \mathrm{~mL}$ (116 mg, $1.15 \mathrm{mmol}$ ) of diisopropylamine (DIPA), and then $0.36 \mathrm{~mL}$ ( $250 \mathrm{mg}, 2.55 \mathrm{mmol}$ ) of trimethylsilylacetylene (6). The reaction mixture was allowed to stir overnight at room temperature, after which time the solvent was evaporated in vacuo, the residue was suspended in hexane and then filtered through a bed of celite. The filtrate was concentrated under reduced pressure, chromatographed using silica gel and hexane as eluent, and then recrystallized from EtOH- $\mathrm{H}_{2} \mathrm{O}$ to 
give 22 as a white, crystalline solid (53 $\mathrm{mg}, 29 \%$ yield). EIMS $m / z(\%): 284\left(\mathrm{M}^{+}, 65\right), 214$ (65), 199 (100). UV-vis (THF) $\lambda_{\max }(\mathrm{nm}): 214,240,275,291,309 . \mathrm{IR}(\mathrm{KBr})\left(\mathrm{cm}^{-1}\right)$ : $2203,2103,1603,1509,1299,1249,1172,1108,1048$, 1014, 847, 760, 694. 'H NMR $\left(\mathrm{CDCl}_{3}\right) \delta: 7.41$ (d, $J=$ $8.7 \mathrm{~Hz}, 2 \mathrm{H}), 6.83(\mathrm{~d}, J=8.7 \mathrm{~Hz}, 2 \mathrm{H}), 3.59(\mathrm{~s}, 2 \mathrm{H}), 1.03(\mathrm{~s}$, 9H), $0.23(\mathrm{~s}, 9 \mathrm{H}) .{ }^{13} \mathrm{C} \mathrm{NMR}\left(\mathrm{CDCl}_{3}\right) \delta: 160.72,134.49$, $114.89,113.06,90.03,88.41,78.13,77.48,73.13,32.08$, 26.77, -0.10. Anal. calcd. for $\mathrm{C}_{18} \mathrm{H}_{24}$ OSi: C 76.00, $\mathrm{H} 8.50$; found: C 76.07, H 8.20.

\section{1-(p-Neopentoxyphenyl)-1,3-butadiyne (23)}

To a stirred solution of $1.0 \mathrm{~g}(3.5 \mathrm{mmol})$ of (22) dissolved in $50 \mathrm{~mL}$ of $\mathrm{MeOH}$ was added $2.1 \mathrm{~mL}(11 \mathrm{mmol})$ of $5 \mathrm{M}$ $\mathrm{NaOH}$. After $15 \mathrm{~min}$, the reaction mixture was acidified with $1 \mathrm{M} \mathrm{HCl}$, extracted twice with hexane, and the extracts were dried over $\mathrm{MgSO}_{4}$. Filtration, followed by evaporation of the filtrate in vacuo gave a grey solid, which after chromatography through a plug of silica gel using hexane, afforded $709 \mathrm{mg}$ of 23 as a white solid, which rapidly darkened on exposure to light and air (95\% yield). (This material was used immediately in the synthesis of 24). EI-MS $m / z(\%)$ : $212\left(\mathrm{M}^{+}, 20\right), 142(100)$. UV-vis (THF) $\lambda_{\max }$ (nm): 214, 281,298 . IR $(\mathrm{KBr})\left(\mathrm{cm}^{-1}\right): 2204,1896,1602,1562,1509$, $1473,1400,1364,1295,1255,1170,1109,1048,1017,921$, 834, 624. ' $\mathrm{H} \mathrm{NMR}\left(\mathrm{CDCl}_{3}\right) \delta: 7.45$ (d, $\left.J=8.6 \mathrm{~Hz}, 2 \mathrm{H}\right), 6.85$ $(\mathrm{d}, J=8.7 \mathrm{~Hz}, 2 \mathrm{H}), 3.61(\mathrm{~s}, 2 \mathrm{H}), 2.46(\mathrm{~s}, 1 \mathrm{H}), 1.04(\mathrm{~s}, 9 \mathrm{H})$. ${ }^{13} \mathrm{C}$ NMR $\left(\mathrm{CDCl}_{3}\right) \delta: 160.86,134.59,114.93,112.74,78.18$, $75.99,72.50,70.87,68.69,32.09,26.76$.

\section{4,5-Di[4-(p-neopentoxyphenyl)-1,3- butadiynyl]phthalonitrile (24)}

The same procedure was used as for the synthesis of 3 , using $631 \mathrm{mg}(1.66 \mathrm{mmol})$ of $1,740 \mathrm{mg}(3.49 \mathrm{mmol})$ of 23 , $122 \mathrm{mg}(0.174 \mathrm{mmol})$ of $\mathrm{Pd}\left(\mathrm{PPh}_{3}\right)_{2} \mathrm{Cl}_{2}, 33.2 \mathrm{mg}$ $(0.174 \mathrm{mmol})$ of $\mathrm{CuI}$, and $40 \mathrm{~mL}$ of TEA, except that the entire reaction was carried out at room temperature. After $18 \mathrm{~h}$, the solvent was removed in vacuo and then the residue was dissolved in $\mathrm{CH}_{2} \mathrm{Cl}_{2}$, washed with $\mathrm{H}_{2} \mathrm{O}$ and brine, dried over $\mathrm{MgSO}_{4}$ and filtered. The solvent was removed from the filtrate under reduced pressure and the brown residue was triturated twice with ethyl ether to leave 24 as a goldenyellow solid (683 $\mathrm{mg}, 75 \%$ yield), mp $233^{\circ} \mathrm{C}$ (decomp.). HR-MS (m/z) calcd. for $\mathrm{C}_{38} \mathrm{H}_{32} \mathrm{~N}_{2} \mathrm{O}_{2}$ : 548.2464; found: 548.2464. UV-vis (THF) $\lambda_{\max }(\mathrm{nm}): 218,262,280,294$, 308, 386. IR $(\mathrm{KBr})\left(\mathrm{cm}^{-1}\right): 2203(\mathrm{C} \equiv \mathrm{N})$. ${ }^{1} \mathrm{H}$ NMR $\left(\mathrm{CDCl}_{3}\right)$ $\delta: 7.86(\mathrm{~s}, 2 \mathrm{H}), 7.52(\mathrm{~d}, J=8.7 \mathrm{~Hz}, 4 \mathrm{H}), 6.89(\mathrm{~d}, J=8.7 \mathrm{~Hz}$, 4H), $3.63(\mathrm{~s}, 4 \mathrm{H}), 1.05(\mathrm{~s}, 18 \mathrm{H}) .{ }^{13} \mathrm{C}-\mathrm{NMR}$ (acetone-d 6$) \delta$ : $162.76,138.72,135.69,131.19,116.38,116.24,115.64$, $113.14,88.62,85.03,79.13,77.41,72.81,32.67,26.96$.

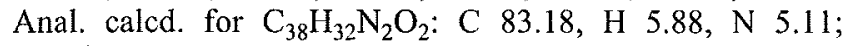
found: $\mathrm{C} 81.14, \mathrm{H} 5.64, \mathrm{~N} 4.76$.

\section{Dilithium-2,3,9,10,16,17,23,24-octa[4-( $p$ -}

neopentoxyphenyl)-1,3-butadiynyl]phthalocyanine (26)

To a vigorously stirred suspension containing $25 \mathrm{mg}$ $(0.046 \mathrm{mmol})$ of $24 \mathrm{in} 0.4 \mathrm{~mL}$ of 1-octanol, was added $4 \mathrm{mg}$ $(0.58 \mathrm{mmol})$ of lithium metal (rolled to a foil in an argon purged plastic bag). The reaction mixture was heated to $80^{\circ} \mathrm{C}$ overnight, after which time the colour turned from bright yellow to dark green. The reaction mixture was di- luted with $10 \mathrm{~mL}$ of hexane and then centrifuged. The supernatant liquid was discarded, the crude pigment was dissolved in anhydrous THF, reprecipitated into $5 \mathrm{~mL}$ of hexane and centrifuged again. This cycle was repeated four times until the octanol was removed and the supernatant liquid was colourless. The remaining crude $\mathrm{Pc}$ was dissolved in 2-mL of anhyd THF and loaded onto a gel permeation column consisting of SX-2 Biobeads ${ }^{\text {B }}$ and anhyd THF as the eluting solvent. A single green band was collected in five, $2 \mathrm{~mL}$ fractions, each of which were analyzed by UV-vis spectroscopy. The fractions containing the least intense absorptions in the $200-500 \mathrm{~nm}$ region of the spectrum were combined and the solvent removed in vacuo to give what is believed to be $\mathbf{2 6}$ as a dark green solid ( $7 \mathrm{mg}, 28 \%$ yield). MALDI-MS $m / z: 2202\left(\mathrm{M}^{+}-\mathrm{Li}\right)$. UV-vis (THF) $\lambda_{\max }(\mathrm{nm})$ : $214,304,408,660,738$. ' $\mathrm{H}$ NMR (pyridine- $d_{5}, 4.53 \times 10^{-4} \mathrm{M}$, $300 \mathrm{~K}) \delta: 9.98(\mathrm{br}, 8 \mathrm{H}), 7.67(\mathrm{~d}, J=8.4 \mathrm{~Hz}, 16 \mathrm{H}), 6.92(\mathrm{~d}, J$ $=8.4 \mathrm{~Hz}, 16 \mathrm{H}), 3.60(\mathrm{~s}, 16 \mathrm{H}), 1.08(\mathrm{~s}, 72 \mathrm{H})$.

\section{Conclusion}

We have demonstrated that it is possible to prepare octaarylethynyl and octaarylbutadiynyl phthalocyanines, but that solubility and stability problems may make their use in nonlinear optics and other applications difficult. Solubilizing groups on the aryl groups ortho to the alkyne groups may provide the dual goal of solubilization and stabilization.

\section{Note added in Proof}

One different octaarylethynylphthalocyanine has recently been reported (see R. Faust and F. Mitzel. J. Chem. Soc. Perkin Trans. 1, 3746 (2000)).

\section{Acknowledgement}

We are grateful to the Natural Sciences and Engineering Research Council of Canada (NSERC) for financial support of this research.

\section{References}

1. (a). C.C. Leznoff. In Phthalocyanines: properties and applications. Vol. 1 Edited by C.C. Leznoff and A.B.P. Lever. VCH Publishers, New York. 1989. pp. 1-54; (b) G. De La Torre, C.G. Claessens, and T. Torres. Eur. J. Org. Chem. 2821 (2000); (c) N.B. McKeown, I. Chambrier, and M.J. Cook. J. Chem. Soc. Perkin Trans. 1, 1169 (1990); (d) C.C. Leznoff. Can. J. Chem. 78, 167 (2000); (e). M. Hanack and M. Lang. Adv. Mater. (Weinheim Ger.), 6, 819 (1994).

2. F.H. Moser and A.L. Thomas. The phthalocyanines. Vols. 1 and 2. CRC Press, Boca Raton, Florida. 1983.

3. A.W. Snow and W.R. Barger. In Phthalocyanines: properties and applications. Vol. 1. Edited by C.C. Leznoff and A.B.P. Lever. VCH Publishers, New York. 1989. pp. 341-392.

4. H.S. Nalwa and J.S. Shirk. In Phthalocyanines: propertics and applications. Vol. 4. Edited by C.C. Leznoff and A.B.P. Lever. VCH Publishers, New York. 1996. pp. 79-181.

5. J.J. Dougherty. Photochem. Photobiol. 58, 895 (1993).

6. R. Boyle and D. Dolphin. Photochem. Photobiol. 65, 469 (1996). 